\title{
Aşçıların Meslek Uyumu ve Meslek Algısı Düzeyleri Üzerine Bir Araştırma
}

\author{
Arif Yılmaz ${ }^{a^{*}}$, Haluk Tanrıverdi ${ }^{b}$ \\ ${ }^{a} \dot{I}$ stanbul Büyükşehir Belediyesi, İstanbul. \\ ${ }^{b} \dot{I}$ stanbul Üniversitesi, İktisat Fakültesi, İstanbul.
}

\section{$\ddot{O} z$}

Bu çalışmanın amacı işgörenlerin, meslek uyumu ile meslek algısı arasındaki ilişkilerin belirlenmesidir. Bu amaç doğrultusunda aş̧̧ların meslek uyumu ve meslek algısı düzeyleri araştırılmıştır. Veriler 2014 yılında Alanya'da düzenlenen Altın Kepçe Uluslararası Yemek Yarışması'na katılan aşçlardan anket yoluyla elde edilmiş olup, bulgular bu ankete katılan 163 aş̧̧ı ile sınırlıdır. Ankete katılanlar kolayda örnekleme yoluyla belirlenmiştir. Araştırmada elde edilen veriler SPSS (Statistical Package for Social Sciences) 22.0 programı kullanlarak analiz edilmiştir. Veriler değerlendirilirken tanımlayıcı istatistiksel metodları (sayı, yüzde, ortalama, standart sapma) kullanılmıştır. Bağımsız iki grubun karşılaştırılmasında Mann Whitney U testi, ikiden fazla grup karşılaştırmalarında ise Kruskal Wallis testi kullanılmıştır. Araştırmanın bağımlı ve bağımsız değişkenleri arasındaki ilişkiyi Pearson korelasyon, etki ise regresyon analizi ile test edilmiştir. Araştırmaya katılan aşçıların Kişi-Meslek Uyumu düzeyi "çok yüksek" ve Genel Meslek Algısı düzeyi "yüksek" olarak saptanmıştır. Kişi-Meslek Uyumu ile Mesleki Genel Algı arasında orta düzeyde, pozitif yönlü anlaml ilişki tespit edilmiştir.

Anahtar Kelimeler: Kişi-Meslek Uyumu, Meslek Alg̨ısı, Aş̧̧ı (Şef).

\section{A Research on Levels of Occupational Fit and Occupational Perception of Cookers}

\begin{abstract}
The aim of this study is to determine the relations between occupational adaptation and occupational perception. For this purpose, the profession adjustment and profession perception levels of the cooks were investigated. The data were obtained through questionnaires from the chefs participating in the Golden Grab International Food Contest held in Alanya in 2014 and the findings are limited to 163 cooks participating in this survey. Survey participants were easily sampled. The data obtained in the study were analyzed using SPSS (Statistical Package for Social Sciences) 22.0 program. Descriptive statistical methods (number, percentage, mean, standard deviation) were used when the data were evaluated. The Mann Whitney $U$ test was used for comparison of quantitative data and the Kruskall Wallis test was used for more than one group comparisons. The relationship between the dependent and independent variables of the study was tested by Pearson correlation and the effect was tested by regression analysis. The level of Occupational Adaptation was found to be "very high" and the level of General Occupational Perception was "high". There was a moderate level positive relationship between the person occupational adjustment and the occupational general perception.
\end{abstract}

Keywords: Person-Occupation Fit, Occupation Perception, Cook (Chef). 


\section{GíRiş}

Meslekler insan hayatında oldukça uzun süreli yer alan uğraşımlardır (İlhan, 2008: 2; Eke, 1987: 377). TDK Meslek kavramını, "belli bir eğitim ile kazanılan sistemli bilgi ve becerilere dayalı, insanlara yararlı mal üretmek, hizmet vermek ve karşılığında para kazanmak için yapılan, kuralları belirlenmiş iş" şeklinde tanımlamaktadır (www.tdk.gov.tr; Tak ve Çiftçioğlu, 2008: 156, Akalın, 2006: 24).

İş kavramı ile meslek kavramı farklı anlamlar içermektedir (Aytaç, 2000: 198; Çakır, 2001: 33). Meslek, geçim sağlama yönünde verilen bir uğraş olmanın ötesinde, toplumsal bir olgudur ve içinde birçok toplumsal ögeyi içinde barındırmaktadır (İlhan, 2008: 132-133). Meslek olgusu çoğunlukla bireylerin bilinçli tercihleri iken "iş" olgusu ise tercihten daha ziyade piyasa koşullarına göre meslek dişında da olabilen faaliyetleri ifade etmektedir (Çakır, 2001: 33). Merih ve Arslan, (2012)'a göre profesyonel bir meslek temelinde, meslek bağlılığı ve örgütlenmeyi barındırmaktadır.

Meslek, bireyin toplum içerisinde kendisini tanımlama ve yer edinmesinde en önemli etkenlerden biri olarak kabul edilmekte, kişisel gelişimi ve kendini gerçekleştirmesine olanak sağlamaktadır (İlhan, 2008). Bu doğrultuda meslek kavramını; bireyin kişiliğinin en önemli bileşeni olarak etraftan saygı görmesini, başkalarıyla ilişki kurmasını sağlayan ve belirli kültürel özelliklere, bakış açılarına, yaşam tarzlarına, değerlere, ilkelere vb. sahip bireyler tarafından icra edilen toplumsal değere sahip bir olgu olarak ifade etmek mümkündür (Kuzgun, 2000).

\section{AŞÇILIK MESLEĞİ}

Eren, (2016: 84). “Türkiye'nin Gastronomi İmajı, Ziyaretçilerin Bilgi Kaynakları Ve Harcamaları" konulu doktora çalışmasında, Gastronomi imajının destinasyonunu tekrar ziyaret etme niyeti üzerinde etkisi olduğu, seyahat boyunca yiyecek ve içecek harcamaları ortalamasının $575 \$$ olduğu ve bu tutarın seyahat bütçelerinde $\% 18,8^{\prime}$ lik bir pay aldığı bulgusuna ulaşılmıştır.

Mesleki Eğitim ve Geliştirme Projesi (MEGEP 2007: 12), aşçıyı; "kendi başına ve belirli bir süre içerisinde kahvaltıları, çorbaları, zeytinyağh yemekleri, mezeleri, hamur işi yemeklerini, salataları, sıcak ve soğuk sosları, kırmızı et, kümes hayvanları, sakatat ve av hayvanları yemeklerini, su ve deniz ürünleri yemeklerini, sebze ve kuru baklagil yemeklerini, pilav ve makarna yemeklerini, tathları ve içecekleri kendi başına hazırlama bilgi ve becerisine sahip nitelikli kişi" şeklinde tanımlamaktadır.

Mesleki aşçılık eğitiminin, işletmelerde maliyetleri düşürücü, verimliliği ve karlılığı arttırıcı, faydaları olduğu bilinmektedir. Nitelikli mutfak çalışanı okul, kurs, kitap, usta-çırak ilişkisi vb. kaynaklardan beslenerek teorik mutfak bilgisini almış, sektörde çalışarak teoriyi pratiğe dökmüş, mesleğini severek yapan ve kendini yenileyen kişi olarak tanımlanmaktadır (Şükran, 2015: 102-103). 


\section{Kİşİ MESLEK UYUMU}

Mesleğin icrası için gereken bilgi, beceri, tavır ve tutumlar ile gerekli iş süreç bilgileri bir araya geldiğinde, mesleğini severek ve isteyerek yapan bir meslek erbabi ile birlikte toplumsal kabul ve itibarı gören bir meslek ortaya çıkar (Arınç, 2013: 138).

Bireyler kendine ögzü farklı yatkınlık, bilgi, beceri ve ilgi alanlarına sahip olup, bu farklılıklar sebebiyle bazı meslekler birey açısından daha çekici hale gelir (Starks ve Glenn, 2007: 61). Yapılan araştırmalarda birey-meslek uyumu düzeyi yüksek kişilerin, mesleklerini devam ettirme eğilimlerinin, birey-meslek uyum düzeyleri düşük olan kimselerin ise, meslek değiştirme eğilimlerinin daha yüksek olduğu ortaya çıkmıştır (Donohue, 2006). Gothard (2001), Mesleğin icrası için gerekli bilgi ve beceri düzeyi ile bireyin nitelikleri arasında uyum olması durumunda, birey olumlu meslek algisına sahip olacak ve mesleğinde uzun süre çalışma motivasyonuna kavuşacağını ifade ederken, Carless, (2005) ve Vandenberghe ve Ok, (2013) birey meslek uyumu düzeyi mesleki tatmin ve bağl1lık düzeyine olumlu yönde etki etmekte olduğundan söz etmektedir.

Bireyin sahip olduğu meslek, yaşam tarzının ortaya çıkmasında önemli rol olmaktadır. Meslek, bireye ekonomik kazanç, toplumsal statü, bedensel ve zihinsel gelişim sağlamakta, hayata bakış açısı, olaylar karşısındaki tutum ve davranışları ile toplumsal ilişkilerine yön vermektedir (İlhan; 2008: 314). Bireyin kimlerle arkadaş olacağ1 ve zaman geçireceğini, kiminle evlenip evlenemeyeceğini, yaşayacağ 1 muhiti, çocuklarının geleceği ve ailesinin hayat kalitesini de sahip olduğu meslek belirler (Eke, 1987: 378-379).

Aşçlılk mesleğinde istekli olmak çok önemlidir (Şükran, 2015: 102-103). Turizm sektörü çalışanlarına göre turizm işletmelerinde çalışan personelde bulunması geren en önemli özellikler sırasıyla; "teoriyi pratiğe iyi uyarlayabilmek', deneyim, turizm eğitimi almak ve yabancı dil bilgisidir" (Şükran, 2015: 90).

Arbak ve Yeşilada, (2003: 23) “Örgüt Kişi Uyumu ve Örgütsel Çekicilik: Hangi Kişiler Ne Tür Örgütleri Daha Çekici Bulur?" adlı çalışmasında örgütlerin kendilerine uygun elemanları istihdam etmek ve onları sosyalleştirmek için yoğun çaba harcadığından ve bu çabanın rekabet avantajı sağlayacak güçlü örgütsel kültür oluşturmaya yönelik olduğundan söz etmektedir. Öz güveni zayıf kişilerin, güçlü olanlara oranla iş güvencesi sağlayan örgütleri, özgüveni yüksek kişilerin ilgi alanlarına uygun, yenilikçi, eğitim imkânı sağlayan işletmeleri tercih ettiği bulgusunu elde etmiştir.

Ültanır, (2000: 1) Üniversite öğrencilerinin edinecekleri mesleklere uyum seviyesini ölçmek için bir araç geliştirmek ve bu ölçüm aracının geçerlik ve güvenirliğinin tespiti amacıyla yaptı̆̆ı çalışmada; "Mesleksel Üretkenlik, Mesleksel Beceriler, Mesleksel Yeterlilik ve Mesleksel Olanaklar" olmak üzere dört boyut elde etmiştir.

Çelebi ve Ülker, (2013: 127) Yükseköğretim kurumlarında çalışan İngilizce okutmanlarının uyum algı ve davranışlarını etkileyen unsurları incelemek amacıyla 
yaptığı "Yükseköğretim Kurumlarında Eğitimci Bireylerin Uyum Alg1 Ve Davranışlarını Etkileyen Unsurlar" isimli nitel çalışmasında, katılımcılardan elde edilen verileri, "Yönetici, Meslektaş ve Öğrencilerle ilişkiler, İşin Yapısına İlişkin Özellikler, Kurum Yapısı ve Kültürüne İlişkin Özellikler ve Çalışma Ortamına İlişkin Özellikler" olarak sınıflandırmıştır.

\section{MESLEK ALGISI}

Mesleklerin, meslek sahibinin kendi kimliğine yönelik etkisinin yanı sıra, kişinin toplum tarafindan algılanmasına dair bir referans olmasından dolayı da mesleki alg1 çok önemlidir (Macit, 2007: 37). Bir mesleğin sosyal statüsünün yüksek oluşu mesleği daha prestijli hale getirmekte ve bireyin mesleğine yönelik algısını da şekillendirmektedir (Kuşluvan ve Kuşluvan, 2000). Akalın, (2006) bireylerin mesleklerini bilinçli olarak seçmelerinin, meslek algılarını olumlu yönde geliştireceğini ve bu bireylerin daha mutlu ve huzurlu bir hayat süreceğini ifade etmektedir. Ayrıca, bireyin meslek algısının bir takım davranışsal sonuçları da bulunmakta (Aytaç, 2000) olup, meslek algısı ile mesleği sürdürme niyeti arasında doğrusal, meslekten uzaklaşma arasında önemli düzeyde ters ilişki söz konusudur (Wildes, 2004).

Emek-yoğun bir özellik taşıyan ve insan ilişkilerinin ön plana çıktığı turizm endüstrisi/sektörü içerisindeki otel işletmelerinde çalışanların "mesleki bağlılığı" ile "mesleği bırakma niyeti" üzerinde etkisi yadsınamayacak iki temel faktör olan "bireymeslek uyumu" ve "mesleki sosyal statü alg1sı" görgül olarak incelenmiştir. Araştırmanın sonucunda, birey-meslek uyumu ve mesleğin sosyal statüsüne ilişkin algının mesleki bağlılık üzerinde anlamlı ve pozitif etkisi olduğu tespit edilmiştir. Öte yandan, mesleki bağlllı̆̆ın ise, mesleği bırakma niyeti üzerinde negatif etkisi olduğu sonucuna ulaşılmıştır (Saltık vd., 2016: 42).

Ayrıca yapılan araştırmalarda, turizm eğitimi alan öğrencilerin mesleği tercihinde, mesleğin sosyal statü değeri ve prestij algısı faktörünün ağır bastığı (Wang ve Liu, 2010), otel işletmeleri çalışanlarının genel iş tatmin düzeyini en fazla etkileyen faktörler işin niteliği ve toplum içerisindeki imajı olduğu (İnce, 2008), hemşirelerin mesleki tatmin düzeylerinin düşük olmasının, mesleğin toplumsal imajının düşük olmasından kaynaklandığı (Karakuş, 2011) ifade edilmiştir.

Mesleğe ilişkin davranış, tutum ve dünya görüşü, bireyin mesleğine karşı kendi içindeki algısını ifade etmektedir (Eke, 1987: 378-379). Mesleki getiriler de bireylerin beklentilerinde önemli bir etkendir. Bu beklentilerin karşılanması meslek sahibi bireyin tatmin duygusunu etkilemekte bu tatmin duygusu da mesleği benimseme düzeyine yansımaktadır (Aca vd., 2013: 150-151). Akalın (2006: 53-56)' a göre bireyin mesleğine ekonomik kazanımlardan öte anlam yüklemesi onun meslek algısına göre hareket emesine sebep olmakta, meslek seçiminde bu algının etkisi mesleki yeterliliğin de önüne geçebilmektedir.

Halıcı ve Delil, (2003) tarafından Büro Yönetimi Öğrencilerinin Mesleki Algılamalarının Belirlenmesine Yönelik yaptığı çalışmada, öğrencilerin yakın çevrelerinin ve tolumun meslekleri hakkında önemli derecede olumsuz 
düşündüklerini, bunun sebebini mesleğin iyi bilinmemesi ve bu mesleğin eğitim gerektirmediği düşüncesi oluşturduğunu ifade etmektedir.

Dinçer ve Yılmaz, (2015: 9) tarafından, “Dokuz Eylül Üniversitesi ilköğretim Matematik Öğretmenliği Bölümü dördüncü sınıf öğrencilerinin öğretmenlik mesleğine yönelik algı ve umutsuzluk düzeyleri arasındaki ilişki ve bu değerlendirmelerin bağlı olduğu faktörleri" incelemek maksadıyla yapılan araştırmandan, mesleğe yönelik alg1 ve umutsuzluk düzeyleri arasında negatif yönde, anlamlı bir ilişki olduğu saptanmıştır. Öğretmenlik mesleğine yönelik alg1 düzeyi gelir düzeyi, ikamet yeri, anne-baba eğitim düzeyleri değişkenleri açısından anlamlı bir farklılık göstermezken; mesleği seçme nedeni değişkenleri ile anlamlı ilişkisi olduğu bulgusuna ulaşılmıştır.

Erdem, (2012: 1727), genel tarama modelinin bir türü olan ilişkisel tarama modeli ile gerçekleştirdiği, “Türk dili ve edebiyatı öğretmeni adaylarının mesleki yeterlilik algıları ve öğretmenlik mesleğine ilişkin tutumları" incelenmek maksadıyla yaptığı araştırmada sonuç olarak öğretmen adaylarının mesleğe yönelik ilgi ve tutumlarının yüksek olduğu belirlenmiş, özel alan bilgisi ve meslek bilgisi konularında kendilerini yetersiz hissettikleri tespit edilmiştir.

Bir mesleğin toplum nezdindeki kabul ve itibar görmesi o mesleğin seçimindeki en önemli etkenlerden biridir (Arınç, 2013: 138). Bir mesleğin algısı kişiden kişiye değişmekte olup, bu algıyı bir takım faktörler etkilemektedir. Mesleğin toplumdaki saygınlık ve işlevselliği de bu faktörlerin içinde bulunmakta olup, bu saygınlık ve işlevselliği meslek sahibine prestij ve statü olarak geri dönmektedir. Tip, hukuk ve mühendislik gibi meslek mensuplarının toplum için sağladığı katma değer sonucu işlevselliklerinin yüksek olduğu ve bunun sonucunda meslek sahibi kimselerin toplumsal prestijlerinin yükseldiği söylenebilir (Aca, Emirgil ve Işı̆̆ıçok, 2013: 150151). İcra edilen mesleğin, bireye olan katkılarının yanı sıra toplumun gelişimine katkı sağladığını hissettirmesi, bireyin yanında toplum için de yüksek değerde bir meslek statüsü olarak algılanabilir (Çakır, 2001: 56). İçinde bulunduğu toplum bireyin mesleğine önem vermekte ve ona mesleğin statüsüne eşdeğer bir değer atfetmektedir. Buradan hareketle sahip olunan mesleğin, bireyin toplumdaki unvan ve statüsüne ilişkin bir göstergesi olduğu söylenebilir (Ilhan, 2008: 316). Yapılan bir araştırmanın sonucuna göre; Hemşire ve ebelerin mesleklerine ilişkin algıları, kendilerini toplum içinde nasıl gördüklerini ve motivasyonlarını etkilerken, ayrıca iş yaşamındaki performansları üzerinde de etkili olabilmektedir (Yılmaz vd., 2013).

\section{METODOLOJi}

Kişilerde oluşan meslek algısı, mesleki uyum ile ilişkili midir? ve meslek uyumu, meslek algısını etkilenmekte midir? problemine cevap bulmak amacıyla aşçlar üzerine yapılan bu araştırmanın hipotezleri aşağıdaki gibi kurulmuştur.

- H1: Aşçılarda meslek uyumu ile meslek algıları arasında anlamlı ilişki vardır.

- H2: Aşçıların meslek uyumu düzeyi, meslek algı düzeylerini etkiler. 


\subsection{Evren ve Örneklem}

Araştırmanın evrenini 2014 yılında Alanya'da yapılan Altın Kepçe Turizm ve Aşçılar Derneği 4. Uluslararası Yemek Yarışması'na katılan aşçılar oluşturmaktadır. Söz konusu yarışmaya; Usta şefler, Liseliler, Üniversiteliler, Pizza ve Display dallarında 420 aşçı katılmış olup, ana kitleyi temsil edecek örneklem büyüklügünün belirlenmesinde

$$
n=N t^{2} p q / d^{2}(N-1)+t^{2} p q
$$

N: Hedef kitledeki birey sayısı

n: Örnekleme alınacak birey sayısı

p: İncelenen olayın görülüş sıklı̆̆ı (gerçekleşme olasılı̆̆ı)

q: İncelenen olayın görülmeyiş sıklı̆̆ı (gerçekleşmeme olasılığı)

t: Belirli bir anlamlılık düzeyinde, $t$ tablosuna göre bulunan teorik değer

d: Olayın görülüşs sıklğına göre kabul edilen \pm örnekleme hatasıdır (Salant ve Dillman, 1994, s. 55).

formülü kullanılarak homojen bir yapıda olmayan bu evren için \% 95 güven aralığında, \pm \% 5 örnekleme hatası ile gerekli örneklem büyüklüğü $n=420(1,96)^{2}(0,8)$ $(0,2) /(0,05)^{2}(2200-1)+(1,96)^{2}(0,8)(0,2)=155$ olarak hesaplanmıştır. Araştırma için 350 anket dağıtılmış olup, 170 aşçıdan geri dönüş sağlanmıştır, değerlendirmeler sonrasında kullanılabilir 163 anket elde edilmiştir. Bu sonuçlara göre örneklemin evreni temsil ettiği belirlenmiştir. Örneklemin tanımlayıcı özelliklere göre dağılımı aşağıda verilmiştir.

\subsection{Verilerin Toplanması ve Ölçek Formları}

Veriler, Karaman (2008) tarafından "Öğretmenlerin Mesleklerini Algılama Biçimleri Ve Gelecekten Beklentileri Nelerdir?" Konulu yüksek lisans proje çalışması için geliştirilen ve Yılmaz, Şen ve Demirkaya (2014) tarafından "Hemşirelerin ve Ebelerin Mesleklerini Algılama Biçimleri ve Gelecekten Beklentileri" araştırmasında kullanılan anket sorularından seçilerek aşçılara uyarlanan anket yolu ile elde edilmiştir.

\subsubsection{Kişi Meslek Uyumu Ölçeği}

Kişi-meslek uyumu ölçeğinin güvenirliğini hesaplamak için iç tutarlılık katsayısı olan "Cronbach Alpha" hesaplanmıştır. Ölçeğin genel güvenirliği Alpha $=0.667$ olarak kabul edilebilir düzeyde bulunmuştur. Ölçeğin yapı geçerliliğinin ortaya koymak için açıklayıcı(açımlayıcı) faktör analizi yöntemi uygulanmıştır. Yapılan Barlett testi sonucunda $(\mathrm{p}=0.000<0.05)$ faktör analizine alınan değişkenler arasında ilişkinin olduğu tespit edilmiştir. Yapılan test sonucunda $(\mathrm{KMO}=0.673>0,60)$ örnek büyüklügünün faktör analizi uygulanması için yeterli olduğu tespit edilmiştir. Faktör analizi uygulamasında varimax yöntemi seçilerek faktörler arasındaki ilişkinin yapısının aynı kalması sağlanmıştır. Faktör analizi sonucunda değişkenler toplam açıklanan varyansı \%64,181 olan tek faktör altında toplanmıştır. Güvenirliğine ilişkin 
bulunan Alpha ve açılanan varyans değerine göre Kişi meslek uyumu ölçeğinin geçerli ve güvenilir bir araç olduğu anlaşılmıştır. Ölçeğe ait oluşan faktör yapısı Tablo 1 'de görülmektedir.

Tablo 1. Kişi Meslek Uyumu Ölçeği Faktör Yapısı

\begin{tabular}{|c|c|c|c|c|c|c|}
\hline & & Alfa & KMO & $\mathbf{P}$ & $\begin{array}{l}\text { Faktör } \\
\text { Yükü }\end{array}$ & $\begin{array}{l}\text { Açılklanan } \\
\text { Varyans }\end{array}$ \\
\hline \multirow{3}{*}{$\begin{array}{l}\text { F:1 KIŞİ } \\
\text { MESLEK } \\
\text { UYUMU } \\
\text { Özdeğer: } 1,925\end{array}$} & $\begin{array}{l}\text { Mesleğimin, kişilik } \\
\text { özelliklerime uygun } \\
\text { olduğunu } \\
\text { düşünüyorum. }\end{array}$ & \multirow{3}{*}{0,667} & \multirow{3}{*}{0,673} & \multirow{3}{*}{0,000} & 0,823 & \multirow{3}{*}{64,181} \\
\hline & $\begin{array}{l}\text { Mesleğimi severek } \\
\text { yapıyorum. }\end{array}$ & & & & 0,813 & \\
\hline & $\begin{array}{l}\text { Mesleğimden } \\
\text { yeterince doyum } \\
\text { sağliyorum. }\end{array}$ & & & & 0,767 & \\
\hline
\end{tabular}

\subsubsection{Meslek Algısı Ölçeği}

Meslek algısı ölçeğinin güvenirliğini hesaplamak için iç tutarlılık katsayısı olan "Cronbach Alpha" hesaplanmıştır. Ölçeğin genel güvenirliği Alpha=0.766 olarak iyi düzeyde bulunmuştur. Ölçeğin yap1 geçerliliğinin ortaya koymak için açılayıcı(açımlayıcı) faktör analizi yöntemi uygulanmıştır. Yapılan Barlett testi sonucunda $(\mathrm{p}=0.000<0.05)$ faktör analizine alınan değişkenler arasında ilişkinin olduğu tespit edilmiştir. Yapılan test sonucunda $(\mathrm{KMO}=0.785>0,60)$ örnek büyüklüğünün faktör analizi uygulanması için yeterli olduğu tespit edilmiştir. Faktör analizi uygulamasında varimax yöntemi seçilerek faktörler arasındaki ilişkinin yapısının aynı kalması sağlanmıştır. Faktör analizi sonucunda değişkenler toplam açıklanan varyansı \%59,458 olan iki faktör altında toplanmıştır. Güvenirliğine ilişkin bulunan Alpha ve açıklanan varyans değerine göre meslek algısı ölçeğinin geçerli ve güvenilir bir araç olduğu anlaşılmıştır. Ölçeğe ait oluşan faktör yapısı Tablo 2' de görülmektedir. 
Tablo 2. Meslek Algısı Ölçeği Faktör Yapısı

\begin{tabular}{|c|c|c|c|c|c|c|}
\hline & & Alfa & KMO & $\mathbf{P}$ & $\begin{array}{l}\text { Faktör } \\
\text { Yükü }\end{array}$ & $\begin{array}{l}\text { Açılklanan } \\
\text { Varyans }\end{array}$ \\
\hline \multirow{3}{*}{ 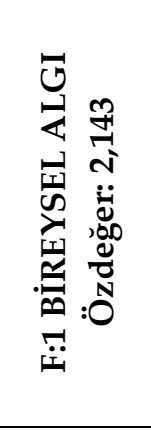 } & $\begin{array}{l}\text { Meslektaşlarımın, mesleki } \\
\text { açıdan yeterli olduğunu } \\
\text { düşünüyorum. }\end{array}$ & \multirow{3}{*}{0,705} & \multirow{3}{*}{0,730} & \multirow{3}{*}{0,000} & 0,740 & \multirow{3}{*}{32,020} \\
\hline & $\begin{array}{l}\text { Mesleki açıdan yetişmemiz için } \\
\text { gerekli imkanların sağlandığını } \\
\text { düşünüyorum. }\end{array}$ & & & & 0,744 & \\
\hline & $\begin{array}{l}\text { Mesleğimin ekonomik } \\
\text { imkanlarının yeterli olduğunu } \\
\text { düşünüyorum. }\end{array}$ & & & & 0,782 & \\
\hline \multirow{4}{*}{ 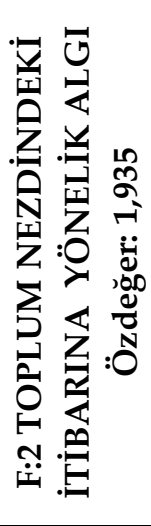 } & $\begin{array}{l}\text { Mesleğimin statüsünün yüksek } \\
\text { olduğunu düşünüyorum. }\end{array}$ & \multirow{4}{*}{0,724} & \multirow{4}{*}{0,670} & \multirow{4}{*}{0,000} & 0,656 & \multirow{4}{*}{27,438} \\
\hline & $\begin{array}{l}\text { Mesleğimin, toplumda en } \\
\text { güvenilen meslekler arasında } \\
\text { olduğunu düşünüyorum. }\end{array}$ & & & & 0,838 & \\
\hline & $\begin{array}{l}\text { Mesleğimin, toplumun } \\
\text { gelişmesine önemli katkılarının } \\
\text { olduğunu düşünüyorum. }\end{array}$ & & & & 0,791 & \\
\hline & $\begin{array}{l}\text { Yaptığım işe toplumun, } \\
\text { yeterince saygı duyduğunu ve } \\
\text { değer verdiğini düşünüyorum. }\end{array}$ & & & & 0,779 & \\
\hline
\end{tabular}

Meslek ölçeğinin faktör analizi değerlendirilmesinde özdeğeri birden büyük faktörlerin ele alınmasına, değişkenlerin faktör içerisindeki ağırlığını gösteren faktör yüklerinin yüksek olmasına, aynı değişken için faktör yüklerinin birbirine yakın olmamasına dikkat edilmiştir. Ölçeği oluşturan faktörlerin güvenirlik katsayıları ve açılanan varyans oranlarının yüksek olması ölçeğin güçlü bir faktör yapısına sahip olduğunu göstermiştir. Birinci faktörde yer alan maddeler Mesleğe Yönelik Bireysel Alg1 olarak ele alınmıştır. Mesleğe Yönelik Bireysel Alg1 faktörünü oluşturan 4 maddenin güvenirliği Alpha= 0.705 olarak, açıklanan varyans değeri \%32.020 olarak saptanmıştır. İkinci faktörde yer alan maddeler Mesleğin Toplum Nezdindeki İtibarına Yönelik Alg1 olarak ele alınmıştır. Mesleğin Toplum Nezdindeki İtibarına Yönelik Alg1 faktörünü oluşturan 3 maddenin güvenirliği Alpha= 0.724, açıklanan varyans değeri $\% 27.438$ olarak saptanmıştır.

\subsection{Verilerin İstatistiksel Analizi}

Araştırmada elde edilen veriler SPSS (Statistical Package for Social Sciences) for Windows 22.0 programı kullanılarak analiz edilmiştir. Verilerin değerlendirilmesinde tanımlayıcı istatistiksel yöntemleri olarak sayı, yüzde, ortalama, standart sapma kullanılmıştır. 
Anket sorularına verilecek yanıtlar 3 seçenekli olarak hazırlanmış olup, her bir soru için alınan yanıtların ortalamaları bulunarak ve 5'li Likert ölçeğine oranlanarak değerlendirilmiştir.

Ölçek boyutlarının aldığı puanlar 1 ile 5 arasında değerlendirilmektedir. $\mathrm{Bu}$ aralık 4 puanlık genişliğe sahiptir. Bu genişlik beş eşit genişliğe ayrılarak 1.00- 1.79 arası "çok düşük", 1.80- 2.59 arası "düşük", 2.60- 3.39 "arası orta", 3.40-4.19 arası yüksek, 4.20-5.00 arası çok yüksek olarak bulgular yorumlanmıştır (http://www.istatistikanaliz.com/faktor_analizi.asp).

Normal dağılım testi sonucunda örnekleme ait verilerin normal dağılmadığı $(\mathrm{p}=0.000)$ görülmüş olup, İki bağımsız grup arasında niceliksel verilerin karşılaştırılmasında Mann-Whitney $U$ testi, ikiden fazla bağımsız grup arasında niceliksel verilerin karşılaştırılmasında ise Kruskal-Wallis H testi kullanılmıştır.

Araştırmanın sürekli değişkenleri arasında pearson korelasyon ve regresyon analizi uygulanmıştır. Korelasyon analizi sürekli değişkenler arasında doğrusal ilişkinin kuvveti (derecesi) ve yönünün belirlemek üzere uygulanır. Araştırmanın sürekli değişkenleri arasında nedensellik ilişkisini belirlemek üzere; bağımsız değişkenler yardımıyla zor elde edilen bağımlı değişken değerini kestirmek için regresyon analizi uygulanır(http://www.istatistikanaliz.com/regresyon_analizi.asp).

Ölçekler arasındaki korelasyon ilişkileri aşağıdaki kriterlere göre değerlendirilmiştir (Kalaycı, 2006, s.116);

\begin{tabular}{cll}
\multicolumn{1}{c}{$r$} & & İlişki \\
\cline { 1 - 1 } & & Çok Zayıf \\
$0,26-0,49$ & & Zayıf \\
$0,50-0,69$ & & Orta \\
$0,70-0,89$ & & Yüksek \\
$0,90-1,00$ & & Çok Yüksek
\end{tabular}

\section{BULGULAR}

$\mathrm{Bu}$ bölümde aşçıların tanımlayıcı özellikleri ve araştırmadan elde edilen verilerin analizi sonucu elde edilen bulgular ve yorumları yer almaktadır.

\subsection{Aşçıların Tanımlayıcı Özelliklerine İlişkin Bulgular}

Aşçıların; cinsiyet, yaş, çalışılan işletme tipi, medeni durum, eğitim düzeyi, turizm sektöründe ve mevcut işyerinde çalışma sürelerini içeren tanımlayıcı özelliklere ilişkin bulgular Tablo 3'te görülmektedir. 
Tablo 3. Aşçıların Tanımlayıcı Özellikleri

\begin{tabular}{|c|c|c|c|}
\hline Tablolar & Gruplar & Frekans(n) & Yüzde (\%) \\
\hline \multirow{3}{*}{ Cinsiyet } & Kadın & 36 & 22,1 \\
\hline & Erkek & 127 & 77,9 \\
\hline & \begin{tabular}{|l|} 
Toplam \\
\end{tabular} & 163 & 100,0 \\
\hline \multirow{5}{*}{ Yaş } & 15-25 Arası & 58 & 35,6 \\
\hline & 26-35 Aras1 & 51 & 31,3 \\
\hline & 36-45 Arası & 38 & 23,3 \\
\hline & 45 Ve üzeri & 16 & 9,8 \\
\hline & Toplam & 163 & 100,0 \\
\hline \multirow{3}{*}{$\begin{array}{c}\text { Çalışılan } \\
\text { İşletme Tipi }\end{array}$} & Konaklama & 39 & 23,3 \\
\hline & Yiyecek-İçecek & 124 & 76,7 \\
\hline & Toplam & 163 & 100,0 \\
\hline \multirow{5}{*}{ Eğitim Düzeyi } & İlköğretim & 37 & 22,7 \\
\hline & Lise & 61 & 37,4 \\
\hline & Önlisans & 22 & 13,5 \\
\hline & Lisans ve Lisansüstü & 43 & 26,4 \\
\hline & Toplam & 163 & 100,0 \\
\hline \multirow{3}{*}{ Medeni Durum } & Bekar & 84 & 51,5 \\
\hline & Evli & 79 & 48,5 \\
\hline & Toplam & 163 & 100,0 \\
\hline \multirow{7}{*}{$\begin{array}{c}\text { Turizm } \\
\text { Sektöründe } \\
\text { Çalışma Süresi }\end{array}$} & $0-2 Y_{11}$ & 25 & 15,4 \\
\hline & 3-5 Yil & 32 & 19,6 \\
\hline & 6-8 Yil & 27 & 16,6 \\
\hline & 9-11 Yil & 16 & 9,8 \\
\hline & $12-14 Y_{11}$ & 11 & 6,7 \\
\hline & $15 Y_{11}$ ve üzeri & 52 & 31,9 \\
\hline & Toplam & 163 & 100,0 \\
\hline \multirow{5}{*}{$\begin{array}{l}\text { Şu Anki Yerde } \\
\text { Çalışma Süresi }\end{array}$} & 0-2 Yil & 81 & 49,7 \\
\hline & 3-5 Yil & 39 & 23,9 \\
\hline & 6-8 Y1l & 18 & 11,0 \\
\hline & 8 Yil üstü & 25 & 15,4 \\
\hline & Toplam & 163 & 100,0 \\
\hline
\end{tabular}

Aşçılar cinsiyet değişkenine göre, \%22,1'i kadın, \%77,9'u erkek; Yaş değişkenine göre, \%35,6'sı 15-25 yaş, \%31,3'ü 26-35 yaş, \%23,3'ü 36-45 yaş ve \%9,8'i 45 ve üzeri yaş gurubunda bulunmaktadır. Çalıştıkları işletme tipine göre, \%23,3'ü konaklama, \%76,7 yiyecek-içecek şeklinde dağılmaktadır. Aşçıların \%22,7'si ilköğretim, \%37,4'ü lise, $\% 13,5$ 'i önlisans ve \%26,4'ü lisans ve lisansüstü eğitime sahiptir. Medeni durum değişkenine göre, \%51,5'i bekar, \%48,5'i ise evlidir. Aşçıların \%15,4'ü 0-2 yıl, \%19,6' sı 35 yıl, \%16,6'sı 6-8 y1l, \%9,8'i 9-11 yıl, \%6,7'si 12-14 yıl ve \%31,9'u 15 yıl ve üzeri olmak üzere turizm sektöründe çalışma tecrübesine sahiptir. Bu aşçıların \%49,7'si 0-2 yıl, 
\%23,9’u 3-5 y1l, \%11'i 6-8 y1l ve \%15,4'ü 8 y1l üstü süredir halen bulunduğu işyerinde çalışmaktadır.

\subsection{Aşçıların Meslek Uyum ve Meslek Algı Düzeylerine İlişkin Bulgular}

Bu bölümde Aşçıların Kişi-Meslek Uyumu, Genel Meslek Algısı, Mesleğin Toplum Nezdindeki İtibarı ve Mesleğe Yönelik Bireysel Alg1 düzeylerine ilişkin tanımlayıcı istatistikler ve bu değişkenler arasındaki korelasyon ilişkisine yer verilmiştir.

Tablo 4. Aşçıların Mesleki Uyum ve Meslek Algısı Düzeyleri

\begin{tabular}{|l|c|c|c|c|c|}
\hline & & Ort. & SD. & Min. & Max. \\
\hline Kişi-Meslek Uyumu & 163 & 4,443 & 0,742 & 1,67 & 5,00 \\
\hline Genel Meslek Genel Algısı & 163 & 3,963 & 0,585 & 1,67 & 5,00 \\
\hline Mesleğe Yönelik Toplumsal İtibar & 163 & 4,200 & 0,985 & 1,67 & 5,00 \\
\hline Mesleğe Yönelik Bireysel Alg1 & 163 & 4,024 & 0,910 & 1,67 & 5,00 \\
\hline
\end{tabular}

Araştırmaya katılan aşçıların "Kişi-Meslek Uyumu” düzeyi çok yüksek $(4,443 \pm$ 0,742); “Genel Meslek Algısı" düzeyi yüksek (3,963 \pm 0,585); “Mesleğin Toplumsal İtibarına Yönelik Alg1" düzeyi çok yüksek (4,200 $\pm 0,985)$; “Mesleğe Yönelik Bireysel Alg1" düzeyi yüksek $(4,024 \pm 0,910)$ olarak saptanmıştır.

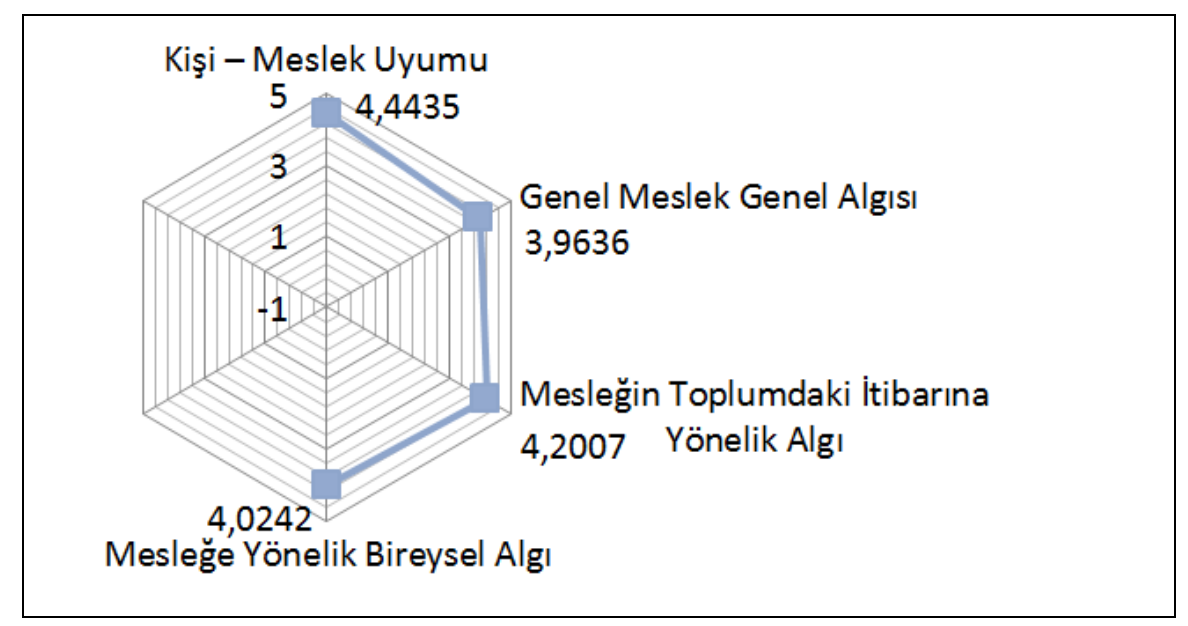

Şekil 1. Aşçıların Kişi-Meslek Uyumu, Genel Meslek Algısı, Bireysel Alg1 ve Toplumsal İtibar Düzeylerine İlişkin Diyagram

Aşçıların Kişi-Meslek Uyumu, Genel Meslek Algısı, Mesleğin Toplum Nezdindeki İtibarı ve Mesleğe Yönelik Bireysel Algı düzeyleri arasındaki korelasyon ilişkisi aşağıda verilmiştir.

Kişi-Meslek Uyumu ile Mesleki Genel Algı arasında orta, pozitif yönde anlamlı ilişki bulunmaktadır $(r=0,613 ; p=0,000<0,05)$. Kişi-Meslek Uyumu ile Mesleğe Yönelik Bireysel Algı düzeyi arasında orta düzeye yakın, pozitif yönde anlamlı ilişki bulunmaktadır ( $r=0,486 ; p=0,000<0,05)$. Kişi - Meslek Uyumu ile Mesleğin toplumsal itibarı arasında zayıf, pozitif ilişki bulunmaktadır $(r=0,389 ; p=0,000<0,05)$. Mesleğe Yönelik Bireysel Algı ile Mesleki Genel Algı arasında orta, pozitif yönde anlamlı ilişki 
bulunmaktadır $(\mathrm{r}=0,622 ; \mathrm{p}=0,000<0,05)$. Mesleğin toplumsal itibarı ile Mesleki Genel Alg1 arasında orta, pozitif yönde anlamlı ilişki bulunmaktadır ( $r=0,610 ; p=0,000<0,05)$. Mesleğin toplumsal itibarı ile Mesleğe Yönelik Bireysel Algı düzeyi arasında zayıf, pozitif yönde anlamlı ilişki bulunmaktadır ( $r=0,440 ; p=0,000<0,05)$.

Kişi-Meslek Uyumu ile Mesleki Genel Algı arasında ilişki olduğunu ifade eden Hipotez (H1) Kabul edilmiştir.

Tablo 5. Kişi-Meslek Uyumu, Genel Meslek Algısı, Bireysel Alg1 ve Toplumsal İtibar Değişkenleri Arasındaki İlişki

\begin{tabular}{|c|c|c|c|c|c|}
\hline & & 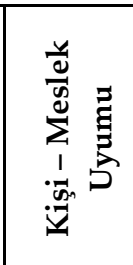 & 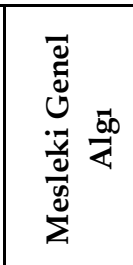 & 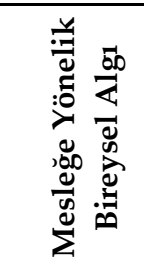 & 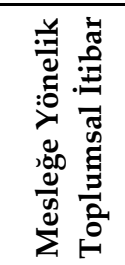 \\
\hline \multirow{2}{*}{ Kişi-Meslek Uyumu } & $\mathrm{r}$ & 1,000 & & & \\
\hline & $\mathrm{p}$ & 0,000 & & & \\
\hline \multirow{2}{*}{ Mesleki Genel Alg1 } & $\mathrm{r}$ & $0,613^{* *}$ & 1,000 & & \\
\hline & $\mathrm{p}$ & 0,000 & 0,000 & & \\
\hline \multirow{2}{*}{ Mesleğe Yönelik Bireysel Alg1 } & $\mathrm{r}$ & $0,486^{* *}$ & $0,622^{* *}$ & 1,000 & \\
\hline & $\mathrm{p}$ & 0,000 & 0,000 & 0,000 & \\
\hline \multirow{2}{*}{ Mesleğe Yönelik Toplumsal İtibar } & $\mathrm{r}$ & $0,389^{* *}$ & $0,610^{* *}$ & $0,440^{* *}$ & 1,000 \\
\hline & $\mathrm{p}$ & 0,000 & 0,000 & 0,000 & 0,000 \\
\hline
\end{tabular}

\subsection{Kişi-Meslek Uyumunun Mesleki Genel Alg1 Üzerine Etkisi}

Kişi-Meslek Uyumu ile Meslek Genel Algısı arasında nedensellik ilişkisi olup olmadığını belirlemek üzere uygulanan regresyon analizi anlamlı bulunmuştur $(\mathrm{F}=92,281 ; \mathrm{p}=0,000<0.05)$. Mesleki Genel Alg1 düzeyinin belirleyicisi olarak Kişi Meslek Uyumu değişkenleri ile ilişkisinin(açıklayıcılık gücünün) güçlü olduğu görülmüştür $\left(\mathrm{R}^{2}=0,372\right)$. Aşçıların Kişi-Meslek Uyumu düzeyi Genel Meslek Alg1sı düzeyini arttırmaktadır $(ß=0,484)$.

Kişi-Meslek Uyumunun Mesleki Genel Alg1 üzerinde etkisi olduğunu ifade eden Hipotez (H2) Kabul edilmiştir.

Tablo 6. Kişi-Meslek Uyumunun Genel Meslek Algısı Üzerine Etkisi

\begin{tabular}{|l|l|l|l|}
\hline & \multicolumn{3}{|c|}{ Mesleki Genel Alg1 } \\
\hline Bağımsız Değişken & $\mathbb{3}$ & $\mathrm{t}$ & $\mathrm{p}$ \\
\hline Sabit & 1,812 & 7,984 & 0,000 \\
\hline Kişi - Meslek Uyumu & 0,484 & 9,606 & 0,000 \\
\hline F & \multicolumn{3}{|c|}{92,281} \\
\hline Model $(\mathrm{p})$ & \multicolumn{3}{|c|}{0,000} \\
\hline $\mathrm{R}^{2}$ & \multicolumn{3}{|c|}{0,372} \\
\hline
\end{tabular}




\subsection{Kişi-Meslek Uyumunun Mesleğe Yönelik Bireysel Algı Üzerine Etkisi}

Kişi-Meslek Uyumu ile Mesleğe Yönelik Bireysel Algı arasında nedensellik ilişkisi olup olmadığını belirlemek üzere uygulanan regresyon analizi anlamlı bulunmuştur $(\mathrm{F}=47,319 ; \mathrm{p}=0,000<0.05)$. Mesleğe Yönelik Bireysel Alg1 düzeyinin belirleyicisi olarak Kişi - Meslek Uyumu değişkenleri ile ilişkisinin(açıklayıcılık gücünün) olduğu görülmüştür $\left(\mathrm{R}^{2}=0,231\right)$. Aşçıların Kişi-Meslek Uyumu düzeyi Mesleğe Yönelik Bireysel Algı düzeyini arttırmaktadır ( $(=0,596)$.

Tablo 7. Kişi-Meslek Uyumunun Mesleğe Yönelik Bireysel Alg1 Üzerine Etkisi

\begin{tabular}{|l|l|l|l|}
\hline & \multicolumn{3}{|l|}{ Mesleğe Yönelik Bireysel Alg1 } \\
\hline Bağımsız Değişken & $\mathbb{t}$ & $\mathrm{t}$ & $\mathrm{p}$ \\
\hline Sabit & 1,375 & 3,524 & 0,001 \\
\hline Kişi - Meslek Uyumu & 0,596 & 6,879 & 0,000 \\
\hline F & \multicolumn{3}{|c|}{47,319} \\
\hline Model $(\mathrm{p})$ & \multicolumn{3}{|c|}{0,000} \\
\hline $\mathrm{R}^{2}$ & \multicolumn{3}{|c|}{0,231} \\
\hline
\end{tabular}

\subsection{Kişi-Meslek Uyumunun Toplum Nezdindeki Mesleki İtibar Üzerine Etkisi}

Kişi-Meslek Uyumu ile Mesleğin Toplum Nezdindeki İtibarı Algısı arasında nedensellik ilişkisi olup olmadığını belirlemek üzere uygulanan regresyon analizi anlamlı bulunmuştur $(\mathrm{F}=27,278 ; \mathrm{p}=0,000<0.05)$. Mesleğin Toplum Nezdindeki İtibarı düzeyinin belirleyicisi olarak Kişi-Meslek Uyumu değişkenleri ile ilişkisinin (açılayıc1lık gücünün) olduğu görülmüştür $\left(\mathrm{R}^{2}=0,146\right)$. Aşçıların Kişi-Meslek Uyumu düzeyi Mesleğin Toplum Nezdindeki İtibarı düzeyini arttırmaktadır $(§=0,516)$.

Tablo 8. Kişi-Meslek Uyumunun Toplum Nezdindeki Mesleki İtibar Üzerine Etkisi

\begin{tabular}{|c|c|c|c|}
\hline & \multicolumn{3}{|c|}{ Mesleğe Yönelik Toplumsal İtibar } \\
\hline Bağımsız Değişken & $\beta$ & $\mathrm{t}$ & $\mathrm{p}$ \\
\hline Sabit & 1,906 & 4,281 & 0,000 \\
\hline Kişi - Meslek Uyumu & 0,516 & 5,223 & 0,000 \\
\hline $\mathrm{F}$ & \multicolumn{3}{|c|}{27,278} \\
\hline Model (p) & \multicolumn{3}{|c|}{0,000} \\
\hline $\mathrm{R}^{2}$ & \multicolumn{3}{|c|}{0,146} \\
\hline
\end{tabular}

\subsection{Aşçıların Tanımlayıcı Özelliklerine Göre Gruplar Arası Farklılıklar}

Bu bölümde aşçıların Kişi - Meslek Uyumu, Genel Meslek Algısı, Mesleğe Yönelik Bireysel Algısı ve Mesleğin Toplum Nezdindeki İtibarı Düzeylerinin tanımlayıcı özelliklere göre değişimleri incelenmiştir.

Araştırma verilerine uygulanan Kolmogorov-Smirnov testi sonucu Tablo 9'da görülmektedir. Meslek Genel Alg1sı $(\mathrm{p}=0,001<0,005)$, Mesleğe Yönelik Bireysel Alg1 $(p=0,000<0,005)$, Mesleğin Toplum Nezdindeki Algısı $(p=0,000<0,005)$ ve Kişi-Meslek Uyumu ( $p=0,000<0,005)$ ortalamalarının normal dağılıma sahip olmadığı görülmüştür. Normal dağılıma sahip olmayan bu veriler için, iki bağımsız grup arasında farklık, 
Mann-Whitney U testi; ikiden fazla grup arasındaki farklılık ise Kruskal-Wallis testi uygulanmak suretiyle araştırılmıştır.

Tablo 9. Verilerin Dağılımına İlişkin Normallik (Kolmogorov-Smirnov) Testi

\begin{tabular}{|c|l|l|l|l|l|}
\hline & N & Ort & Ss & p & Sonuç \\
\hline Kişi-Meslek Uyumu & 163 & 4,443 & 0,742 & 0,000 & \\
\cline { 1 - 5 } Mesleki Genel Alg1 & 163 & 3,963 & 0,585 & 0,001 & \multirow{2}{*}{$\begin{array}{c}\text { p }<, 005 \text { olduğundan dağıllım } \\
\text { normal değildir. }\end{array}$} \\
\hline Bireysel Alg1 & 163 & 4,200 & 0,985 & 0,000 & \\
\hline Toplumsal İtibar & 163 & 4,024 & 0,910 & 0,000 & \\
\hline
\end{tabular}

Sektörde çalışma süresi 3-5 y1l olanlar $(4,387 \pm 0,857 ; \mathrm{U}=-3,024, \mathrm{p}=0,037<0,005)$ ile 15 yıl ve üzeri olan aşçıların Mesleğin Toplum Nezdindeki İtibarına yönelik algı düzeyi puanları $(4,522 \pm 0,761 ; \mathrm{U}=-4,079 ; \mathrm{p}=0,001<0,005), 0-2$ yıl iş tecrübesi olan aşçların puanlarından $(3,403 \pm 0,253)$ daha yüksek bulunmuştur (Tablo 10).

Tablo 10. Sektörde Çalışma Süresine Göre Gruplar Arası Farklılığa Yönelik Bağımsız

Örneklem Kruskal Wallis Testi

\begin{tabular}{|c|c|c|c|c|c|c|c|}
\hline & Grup & $\mathbf{N}$ & Ort & Ss & $\mathrm{U}$ & p & Fark \\
\hline \multirow{6}{*}{ Toplumsal İtibar } & 0-2 Yil (1) & 25 & 3,403 & 253 & \multirow{6}{*}{$-3,024$} & \multirow{4}{*}{0,037} & \multirow{4}{*}{$1<3$} \\
\hline & 3-5 Y1l (2) & 32 & 4,387 & 086 & & & \\
\hline & 6-8 Y1l (3) & 27 & 4,156 & 169 & & & \\
\hline & 9-11 Y1l (4) & 16 & 4,246 & 306 & & & \\
\hline & 12-14 Yil (5) & 11 & 4,056 & 263 & & \multirow[t]{2}{*}{0,001} & \multirow[t]{2}{*}{$1<6$} \\
\hline & 15 Yıl Ve üzeri (6) & 52 & 4,522 & 761 & & & \\
\hline
\end{tabular}

Mevcut İş Yerinde Çalışma Süresi 15 yıl ve üstü olanların Mesleğin Toplum Nezdindeki İtibarı puanları $(4,889 \pm 0,351)$, Aynı İş Yerinde Çalışma Süresi 0-2 yıl olan aşçıların Mesleğin Toplum Nezdindeki İtibarı puanlarından $(3,991 \pm 0,117)$ yüksek bulunmuştur (Tablo 11).

Tablo 11. Şu Anki Yerde Çalışma Süresine Göre Gruplar Arası Farklılığa Yönelik Bağımsız Örneklem Kruskal Wallis Testi

\begin{tabular}{|c|c|c|c|c|c|c|c|}
\hline & Grup & $\mathbf{N}$ & Ort & Ss & $\mathbf{U}$ & p & Fark \\
\hline \multirow{4}{*}{ Toplumsal İtibar } & 0-2 Yil (1) & 81 & 3,991 & ,117 & \multirow{4}{*}{$-3,018$} & \multirow{4}{*}{0,038} & \multirow{4}{*}{$1<4$} \\
\hline & 3-5 Y 11 (2) & 39 & 4,475 & 138 & & & \\
\hline & 6-8 Yil (3) & 18 & 4,167 & 243 & & & \\
\hline & 8 Yıl üstü (4) & 25 & 4,889 & ,351 & & & \\
\hline
\end{tabular}

Yaş değişkenine göre; 36-45 yaş grubu aş̧̧ıların Kişi- Meslek Uyumu puanları $(4,696 \pm 0,879), 15-25$ yaş grubu olan aşçıların Kişi- Meslek Uyumu puanlarından $(4,144$ $\pm 0,126)$ anlamlı düzeyde yüksek bulunmuştur $(U=-3,368 ; p=0,008<0.05)$. 
Tablo 12. Yaşa Göre Gruplar Arası Farklılığa Yönelik Bağımsız Örneklem Kruskal Wallis Testi

\begin{tabular}{|c|c|c|c|c|c|c|c|}
\hline & Grup & $\mathbf{N}$ & Ort & Ss & $\mathbf{U}$ & p & Fark \\
\hline \multirow{4}{*}{ Kişi-Meslek Uyumu } & 15-25 Arası (1) & 58 & 4,144 & , 126 & \multirow{4}{*}{$-3,368$} & \multirow{4}{*}{0,008} & \multirow{4}{*}{$1<3$} \\
\hline & 26-35 Arası (2) & 51 & 4,514 & ,091 & & & \\
\hline & 36-45 Arası (3) & 38 & 4,696 & ,088 & & & \\
\hline & 45 Ve üzeri (4) & 16 & 4,583 & 115 & & & \\
\hline
\end{tabular}

Cinsiyet değişkenine göre yapılan Mann_Whitney U testi sonucu; Erkek aşçıların Kişi-Meslek Uyum puanları $(4,494 \pm 0,068)$, Kadın aşçllara göre $(4,255 \pm 0,123)$ daha yüksek bulunmuştur $(Z=-2,208 ; p=0,027<0.05)$.

Tablo 13. Cinsiyete Göre Bağımsız iki örneklem (Mann Whitney U) Testi

\begin{tabular}{|c|l|c|c|c|c|c|l|}
\hline & \multicolumn{1}{|c|}{ Grup } & N & Ort & Ss & Z & p & Fark \\
\hline \multirow{2}{*}{ Kişi-Meslek Uyumu } & Kadin (1) & 36 & 4,255 &, 123 & \multirow{2}{*}{$-2,208$} & \multirow{2}{*}{0,027} & \multirow{2}{*}{$\mathbf{1}<\mathbf{2}$} \\
\cline { 2 - 6 } & Erkek (2) & 127 & 4,494 &, 068 & & & \\
\hline
\end{tabular}

Tablolardan da görüleceği üzere tanımlayıcı özelliklere göre gruplar arası farklılık yalnız kişi-meslek uyumu ve mesleğin toplumsal itibarı değişkenlerine ilişkindir. Kişi-meslek uyumu, cinsiyet ve yaş değişkenlerine göre, toplumsal itibar, sektörde çalışma süresi ve şu anki yerde çalışma süresine göre gruplar arasında farklılık göstermektedir.

\section{SONUÇ ve TARTIŞMA}

Alanya'da 2014 yılında düzenlenen Altın Kepçe Uluslararası Yemek Yarışması'na katılan aşçılar ile sınırlı olan bu çalışmada; aşçıların "Kişi - Meslek Uyumu" düzeyi çok yüksek $(4,443 \pm 0,742)$; “Genel Meslek Algısı" düzeyi yüksek $(3,964 \pm 0,586)$; “Mesleğin Toplumsal İtibarına Yönelik Alg1" düzeyi çok yüksek $(4,2007$ \pm 0,985); "Mesleğe Yönelik Bireysel Alg1" düzeyi yüksek $(4,024 \pm 0,910)$ olarak saptanmıştır. Yılmaz vd., (2013) Hemşire ve ebelerin meslek algıları üzerine yaptıkları araştırmada mesleklerini severek yapmakla birlikte, mesleğe yönelik algılarının düşük olduğunu tespit etmiştir.

Aşçılık mesleği, sıcak, nem oranı yüksek ve ıslak iş ortamında zorluklarla icra edilmekte olup, kullanılan ekipmanlar ve kimyasallar açısından da iş sağlığı ve güvenliği açısından önem arz etmektedir. Aşçının en temel hazırlık ekipmanı olan keskin bıçaklar muhtelif kesikli yaralanmalara, Islak zeminler kayıp düşmeler sonucu kırıklara, kızartmalar yağ sıçraması sonucu ortaya çıkan yanıklara, sıcak sular haşlanmalara neden olabileceği için son derece dikkatli, düzenli ve iş arkadaşları ile uyumlu çalışılması gereken bir meslektir. Aşçılık Mesleği en temel ihtiyaçlardan olan beslenme ihtiyacına çözüm sunan bir meslek olup, toplum nezdinde her geçen gün artan oranda itibar görmekte ve bu itibar mesleğe yönelik talebi de olumlu yönde arttırmaktadır. Aşçı dernekleri ve öğrenci topluluklarının yaptıkları ulusal ve uluslararası yarışmalar, TV programları, yiyecek içecek bölümünün turizm 
harcamalarından önemli pay alması üstelik müşterinin tekrar ziyaretinde çok önemli bir etken olması da bu mesleğe olan talebi artırmakta ve aşçılık mesleğinin itibarını yükseltmektedir.

Mesleki uyum, mesleğin icrası için gerekli olan bilgi ve beceriler gibi teknik donanımlar yanında iş ortamı, iş koşulları ve iş arkadaşlarına uyum sağlama gibi beşeri ve yönetsel becerilerini de kapsar. İnsan hayatını doğrudan ilgilendiren bu meslekte, temizlik, hijyen ve sanitasyon bilgisinin yanında işgörenlerin bulaşıcı bir hastalık taşınmaması da olmazsa olmaz bir koşuldur. Aşçılar eskiden alaylı diye tabir edilen, usta - çırak ilişkisi çerçevesinde yetişmekte iken, günümüzde meslek liselerinden başlamak üzere lisans düzeyine kadar eğitim alabilmekte ve hatta lisans üstü eğitimlerle belirli alanlarda uzmanlaşabilmektedir.

Kişi-Meslek Uyumu ile Mesleki Genel Algı, Mesleğe Yönelik Bireysel Algı ve Mesleğin toplumsal itibarı arasında pozitif ilişki bulunmaktadır. Mesleğin bireysel alg1s1, meslek seçiminden önce o mesleğin seçilip seçilmeyeceğini, meslek ele alındıktan sonra ise o mesleğin sürdürülüp sürdürülmeyeceğine etki eden en önemli faktörlerin başında gelmektedir. Araştırma sonuçları, birey-meslek uyumu ve mesleki sosyal statü algisının mesleki bağlılık üzerinde etkisi olduğunu ortaya koymakla birlikte, birey meslek uyumunun mesleki bağl1lık üzerindeki etkisinin daha fazla olduğuna işaret etmektedir. Literatürde de, bireyin belirli meslekte kariyer yapma motivasyonuna sahip olmasında özellikle birey-meslek uyumu algısının yüksek olmasının büyük önem taşıdığı belirtilmektedir (Saltık, Avcı ve Kaya 2016: 42-46). Bu kapsamda, Carlesss (2005) kendisiyle mesleğin taşıdığı özellikleri bağdaştırabilen veya bağdaştıramayan çalışanın mesleğini sürdürme veya bırakma isteğinde bulunma eğilimlerinin farklılaşabileceğini belirtmektedir.

Aşçıların Kişi - Meslek Uyumu düzeyi Genel Meslek Algısı düzeyini $(\Omega=0,484)$, Mesleğe Yönelik Bireysel Algı düzeyini $(\Omega=0,596)$ ve Toplum Nezdindeki İtibarı düzeyini $(\Omega=0,516)$ arttırmaktadır. Bulgular literatür ile uyumludur. Gothard (2001), Mesleğin icrası için gerekli bilgi ve beceri düzeyi ile bireyin nitelikleri arasında uyum olması durumunda, birey olumlu meslek algısına sahip olacak ve mesleğinde uzun süre çalışma motivasyonuna kavuşacağını ifade ederken, Carless, (2005), Vandenberghe ve Ok, (2013) birey meslek uyumu düzeyi mesleki tatmin ve bağlılık düzeyine olumlu yönde etki etmekte olduğundan söz etmektedir.

Meslek erbabında, meslek edinmek için alınmış olan eğitim ve yaşanılan çevre sayesinde edindiği zihinsel paradigmaya uygun farklı bir bakış açısı bulunur. Aşçıların bakış açısı ile bir başka meslek mensubunun bakış açısı aynı değildir. Örneğin bir bahçıvan ile bir aşçının sebze/meyveye bakış açısı farklıdır. Bahçıvan daha ziyade yetiştirme ile ilgili bakış sergilerken, aş̧̧ı yemek hazırlama ile ilgili bakış sergileyecektir.

Meslek algısı meslek seçiminde en önemli etkenlerden birisidir. Meslek mensuplarının yaşam ve çalışma koşulları, mesleğin toplum nezdindeki itibarına etki eden hususlardan biridir. Toplum bu tür meslek mensuplarına saygı duymakta ve itibar göstermektedir. Meslek, kişilerin iş ortamı ve çalışma koşullarından iş 
arkadaşlarına, evleneceği eşin seçiminden ikamet ettiği muhite kadar belirleyici bir unsurdur. Meslek toplumsal statünün en temel göstergesidir ve istisnasız her kişi itibarı yüksek bir meslek sahibi olmayı arzu edeceği düşünülmektedir.

\section{- Araştırmacılara;}

- Söz konusu araştırma, konaklama işletmelerinin önbüro, kat hizmetleri ve yiyecek-içecek servisinde çalışan işgörenlere de uygulanabilir.

○ İşgören devir hızı yüksek olan turizm sektöründe kişi meslek uyumu ve meslek algısı değişkenlerinin rolü araştırılabilir.

\section{- Aş̧̧̧ılara;}

○ İşlerini severek yapmaları, gerekli bilgi ve beceri yönünden kendilerini iyi yetiştirmeleri ve sabırlı olmaları böylelikle kişi meslek uyumunu gerçekleştirmeleri,

- Mesleki örgütlenmelerde yer alarak sorunların çözümüne katkı sağlamaları ve mesleklerinin algısını güçlendirmeleri,

\section{- Eğitim Kurumlarına;}

- Lisans düzeyinde eğitim alan aşçılık öğrencilerinin aldıkları teorik eğitimi, pratik uygulamalar ile daha fazla pekiştirmeleri,

\section{- İşletmecilere;}

○ Mesleki aşçılık eğitiminin, işletmelerde maliyetleri düşürücü, verimliliği ve karlılığı arttırıcı etki yaptığından hareketle, mesleğe yönelik eğitim ve gelişime destekleyen bir örgüt iklimi oluşturmaları,

- Adil ücret politikası ve sosyal ortamlar oluşturarak, aşçıların mesleğine saygı duyduklarını uygulamaları ile göstermeleri önerilebilir.

\section{KAYNAKÇA}

Aca, Z., Emirgil, B.F., Işı̆̆ıç̧ok Ö. (2013). Türkiye'de İş Ve Meslek Danışmanlarının Mesleki Algıları Üzerine Nitel Bir Araştırma. I. Uluslararası İş ve Meslek Danışmanlığı Kongresi, Ankara.

Akalın, Ö. (2006). Okul Öncesi Öğretmen Adaylarının Mesleki Algıları İle Geleceğe Yönelik Umut Düzeylerinin Karşılaştııılması (Yayınlanmamış Yüksek Lisans Tezi). İstanbul: Marmara Üniversitesi SBE.

Arbak, Y., Yeşilada, T. (2003). Örgüt Kişi Uyumu ve Örgütsel Çekicilik: Hangi Kişiler Ne Tür Örgütleri Daha Çekici Bulur? Journal of Istanbul Kultur University, 3: 23-37.

Arınç, Ü. D. (2013). Meslek Seçiminde, Meslek Standartları ve Personel Belgelendirmenin Rolü. Uluslararası İş ve Meslek Danışmanlığı Kongresi, 28 - 29 Kasım 2013, Ankara.

Aytaç, S. (2000). İnsanı Anlama Çabası, Bursa: Ezgi Kitabevi.

Carless, S.A. (2005). The Influence of Fit Perceptions, Equal Opportunity Policies, and Social Support Network on Pre-entry Police Officer Career Commitment and Intentions to Remain. Journal of Criminal Justice, 33: 341-352.

Çakır, Ö. (2001). İse Bağlllık Olgusu ve Etkileyen Faktörler, Ankara: Seçkin. 
Çelebi, N. ve Ülker, N. (2013). Yükseköğretim Kurumlarında Eğitimci Bireylerin Uyum Algı ve Davranışlarını Etkileyen Unsurlar. Ĕ̆itim ve Öğretim Araştırmaları Dergisi, 2 (1). ISSN: 2146-9199.

Çetin F., Şeşen H. ve Basım H.N. (2012). Örgüt Kültürünün Rol Ötesi Olumlu Davranışlara Olan Etkisi: Örgütsel Bağlllı̆̆ın Aracı Değişken Rolü. Doğuş Üniversitesi Dergisi, 13 (2), 197 211.

Daylar, Ş. (2015). Otel Mutfak Yöneticilerinin İşgörenlerin Yeterlilik Düzeyi Hakkındaki Algıları: Karşılaştırılmalı Bir Uygulama (Yayınlanmamış Yüksek Lisans Tezi). Balıkesir: Balıkesir Üniversitesi Sosyal Bilimler Enstitüsü Turizm İşletmeciliği Anabilim Dalı.

Dinçer, B. ve Yılmaz, S. (2015). İlköğretim Matematik Öğretmen Adaylarının Mesleğe Karşı Alg1 ve Umutsuzluk Düzeylerinin İncelenmesi. International Journal of New Trends in Arts, Sports ScienceEducation, 4, (2). ISSN: 2146 - 9466.

Donohue, R. (2006). "Person-Environment Congruence in Relation to Career Change and Career Persistence", Journal of Vocational Behavior, 68: 504-515.

Eke, B. (1987). “Bir Sosyal Sınıf Belirleyicisi Olarak Meslek Faktörü”, İstanbul Üniversitesi İktisat Fakültesi Mecmuası, 43: 377-401.

Erdem, C. (2012). Türk Dili ve Edebiyatı Öğretmeni Adaylarının Öğretmenlik Mesleğine Yönelik Yeterlilik Algıları ve Tutumları Üzerine Bir Araştırma. Turkish Studies International Periodical For The Languages, Literature and History of Turkish or Turkic , 7 (4): 1727-1747.

Eren, R. (2016). Türkiye'nin Gastronomi İmajı, Ziyaretçilerin Bilgi Kaynakları ve Harcamaları (Yayınlanmamış Doktora Tez). Ankara: Gazi Üniversitesi Eğitim Bilimleri Enstitüsü.

Gothard, B. (2001). Careers guidance in a new era. İçinde: B. Gothard, P. Mignot, M. Offer ve M. Ruff. Careers guidance in context (ss.1-9). London: Sage Publications.

Halıcı, A. ve Delil Y. (2003). Büro Yönetimi Öğrencilerinin Mesleki Algılamalarının Belirlenmesine Yönelik Bir Uygulama. 22 Nisan 2017 tarihinde http://www.ttefdergi.gazi.edu.tr/makaleler/2003/Sayi1/22-37.pdf adresinden erişildi.

Pak, C. (TY). Radar Grafiği. 25 Nisan 2017 tarihinde http://www.cengizpak.com.tr/5s-calismasiyapanlar-icin-radar-grafigi-ms-excel dosyasi/ adresinden erişildi.

İlhan, S. (2008). Yeni Kapitalizm ve Meslek Olgusunun Değişen Anlamları Üzerine. Dumlupınar Üniversitesi Sosyal Bilimler Dergisi, 21: 313-328.

İnce, C. (2008). Toplam Kalite Yönetimi ve Otel İşletmelerinde İşgören Tatminine Etkileri. Anatolia: Turizm Araştırmaları Dergisi, 19 (1): 57-70.

Kalaycı, Ş. (2006). SPSS Uygulamalı Çok Değişkenli İstatistik Teknikleri. Ankara: Asil Yayın Dağıtım Ltd. Şti.

Karakuş, H. (2011). Hemşirelerin İş Tatmin Düzeyleri: Sivas İli Örneği. Dicle Üniversitesi Sosyal Bilimler Enstitüsü Dergisi, 3 (6): 46-57.

Karaman N. (2008). Öğretmenlerin Mesleklerini Algılama Biçimleri ve Gelecekten Beklentileri Nelerdir? (YayınlanmamışYüksek Lisans Dönem Projesi). Edirne: Trakya Üniversitesi Sosyal Bilimler Enstitüsü. 
Kuşluvan, S. ve Kuşluvan, Z. (2000). Perceptions and Attitudes of Undergraduate Tourism Students Towards Working in the Tourism Industry in Turkey. Tourism Management, 21: 251-269.

Kuzgun, Y. (2000). Meslek Danışmanlığı. Ankara: Nobel Yayın Dağıtım.

Macit, M. (2007). Büyüyünce Ne Olmak İstersin? (Bir Kimlik Belirleme Sorusu Olarak İş/Meslek Üzerine Sosyolojik Bir Yaklaşım). EKEV Akademi Dergisi,30: 35-50.

MEGEP (Mesleki Eğitim ve Öğretim Sisteninin Güçlendirilmesi Projesi), (2007). Yiyecek İçecek Hizmetleri Alanı Çerçeve Eğitim Programı. 22 Nisan 2017 tarihinde http://www.megep.meb.gov.tr/mte_program_modul/program_pdf/cerceve_programlar /cerceve_yiyecek.pdf adresinden erişildi.

Merih, Y.D. ve Arslan, H. (2012). Hemşire ve ebelerin mesleki bilinç-örgütlenmeye yönelik görüşlerinin ve iş doyumlarının belirlenmesi. Hemşirelikte Ĕ̆itim ve Araştırma Dergisi, 9: $3,40-46$.

Priscilla S. ve Dillman, A.D. (1994). How to Conduct Your Own Survey, Newyork: John Wiley \& Sons, Inc.

Starks, G. L. (2007). The Effect of Person-Job Fit on the Retention of Top College Graduates in Federal Agencies. Review of Public Personnel Administration, 27 (1): 59-70.

Tak, B. ve Çiftçioğlu, B.A. (2009). Üç Boyutlu Mesleki Bağlllık Ölçeğinin Türkçe'de Güvenilirlik ve Geçerliliğ̈inin İncelenmesine Yönelik Bir Alan Araştırması, DEÜ İşletme Fakültesi Dergisi, 10 (1): 35-54.

Türk Dil Kurumu. Büyük Türkçe Sözlük, 12 Mart 2015 tarihinde http://www.tdk.gov.tr adresinden erişildi.

Usta, R. (2009). İçsel Pazarlama ve Hizmet Kalitesi Arasındaki İlişki Üzerinde Örgütsel Bağlılık ve İş Tatmininin Aracıllk Etkisi. Erciyes Üniversitesi İktisadi ve İdari Bilimler Fakültesi Dergisi, 34: 241-263.

Ültanır, E. (2000). Üniversite öğrencileri İçin Mesleksel Uyum Envanterinin Geliştirilmesi: Geçerlilik ve Güvenirlik Çalışması. II. Ulusal Öğretmen Yetiştirme Sempozyumu. Çanakkale.

Vandenberghe, C. ve Ok, A. B. (2013). Career commitment, proactive personality, and work outcomes: A cross-lagged study. Career Development International, 18(7): 652-672.

Wildes J. V. (2004). Stigma in Food Service Work: How It Affects Restaurant Servers' Intention to Stay in the Business or Recommend a Job to Another. Tourism and Hospitality Research, 5(3): 213-233.

Wong, S.C.K. ve Liu, G.J. (2010). Will Parental Influences Affect Career Choice? Evidence From Hospitality and Tourism Management Students in China, 22 (1): 82-102.

Yılmaz, T. F., Şen, T. H. ve Demirkaya, F. (2014). Hemşirelerin ve Ebelerin Mesleklerini Algilama Biçimleri ve Gelecekten Beklentileri. Sağlık ve Hemşirelik Yönetimi Dergisi, 1(3): 130-139. 